\title{
28. COMPARISON OF THE ALTERATION AND PETROLOGY OF THE TAITAO RIDGE TO THE TAITAO OPHIOLITE ${ }^{1}$
}

\author{
Viktor Kurnosov, ${ }^{2}$ Randy Forsythe, ${ }^{3}$ Nancy Lindsley-Griffin, ${ }^{4}$ Boris Zolotarev, ${ }^{2}$ Georgy Kashinzev, ${ }^{5}$ \\ Vadim Eroshchev-Shak, ${ }^{2}$ Andrey Artamonov, ${ }^{2}$ and Oleg Chudaev ${ }^{6}$
}

\begin{abstract}
Samples from the Taitao Ridge collected at Site 862, Leg 141, consist of a bimodal suite of subalkalic basalts and dacites to rhyolites. Effusives and sheeted dikes from the Taitao Ophiolite consist of basalts, andesites, and dacites to rhyolites. The ophiolitic basalts are more vesicular than basalts from the Taitao Ridge and are dominated by plagiophyric and pyroxene-plagiophyric textures. Basalts from the Taitao Ridge are dominated by plagioclase-clinopyroxene ( \pm olivine) vitrophyric textures. Geochemically, basalts of both suites fall within the alkaline olivine series, but samples from the Taitao Ridge exhibit more tholeiitic characteristics.

The degree of alteration of basalts from Site 862 on the Taitao Ridge is low (to rarely moderate) with smectite as the main secondary mineral. In contrast, the degree of alteration in the effusives and sheeted-dike complex of the Taitao Ophiolite is moderate to strong, resulting in the development of greenschist facies minerals.

The basalts and silicic volcanic rocks in each suite are comagmatic and may have been derived from a subalkaline primary melt that shared some features with mid-oceanic ridge tholeite basalts (MORB) and with intraplate-rise alkaline basalts. The subalkaline basalts and silicic volcanic rocks comprising the Taitao Ridge and the Taitao Ophiolite may have formed synchronously with Pliocene-Pleistocene arrival of the Chile Rise and Taitao Fracture Zone at the continental slope and shelf. During the complicated interval of trench-transform-trench to trench-ridge-trench triple junction evolution, the ophiolite originally generated from melts within the Taitao Fracture/Transform's collision zone was uplifted and faulted against latest Miocene and Pliocene near-trench plutons and the pre-Late Jurassic metamorphic rocks of the Taitao Peninsula. The uppermost effusives of the ophiolite sequence may have been altered about as much as the Taitao Ridge basalts while in an oceanic setting, and then subjected to additional alteration at the time of emplacement on the continental margin. Alternatively, the higher state of alteration seen in the onshore ophiolitic samples may merely represent differences in the original magmatic/hydrothermal setting, such as the degree of sediment burial, the rates and durations of volcanism, or the age of the samples.
\end{abstract}

\section{INTRODUCTION}

The Taitao Ophiolite lies on the Taitao Peninsula of southern Chile, and the Taitao Ridge is located just offshore from the Taitao Ophiolite, south of the northward-migrating junction between the Chile Rise and the Chile Trench (Fig. 1). Kaeding et al. (1990) hypothesized that the Taitao Ophiolite originated either through magmatic activity associated with Pliocene development of an incipient fore-arc rift during collision of the Chile Rise (just south of the Taitao Fracture Zone) or through structural offscraping of a recently formed fragment of oceanic crust at the subduction zone. Offshore geophysical data discussed by Cande and Leslie (1986) and Cande et al. (1987) support the hypothesis that the Taitao Ridge may represent an offshore extension of the Taitao Ophiolite and that both may have been obducted together as young buoyant oceanic crust located within the Taitao Fracture Zone impinged on the continental margin in the late Pliocene or early Pleistocene. Comparison of the age and geochemical signature of the Taitao Ridge oceanic basement with those of the onshore ophiolite is necessary to determine the origin and kinematic evolution of this zone. The goal of this paper is to present mineralogic and geochemical data that further define the similarities and differences in petrogeochemistry and alteration of the igneous rocks of the Taitao Ridge and the Taitao Ophiolite.

'Lewis, S.D., Behrmann, J.H., Musgrave, R.J., and Cande, S.C. (Eds.), 1995. Proc. ODP. Sci. Results, 141: College Station, TX (Ocean Drilling Program).

${ }^{2}$ Geological Institute, Pyzhevsky Per, 7, Moscow 109017, Russia.

${ }^{3}$ Department of Geography and Earth Sciences, University of North Carolina, Charlotte, NC 29223, U.S.A.

${ }^{4}$ Department of Geology, 214 Bessey Hall, University of Nebraska, Lincoln, NE 68588-0340, U.S.A.

${ }^{5}$ Institute of Oceanology, Krasikov St. 23, Moscow 117218, Russia.

${ }^{6}$ Far East Geological Institute, Vladivostok 690022, Russia.

\section{Site 862: Taitao Ridge}

Site 862 of Leg 141 of the Ocean Drilling Program (ODP) is located near the crest of the Taitao Ridge (Fig. 1). Three holes were drilled at Site 862 . Hole $862 \mathrm{~A}$ penetrated $22.1 \mathrm{~m}$ below seafloor (mbsf), Hole $862 \mathrm{~B}$ to $42.9 \mathrm{mbsf}$, and Hole $862 \mathrm{C}$ to $102.1 \mathrm{mbsf}$. The total sediment thickness at Site 862 is about $23 \mathrm{~m}$. Hole $862 \mathrm{~A}$ contained only two volcanic clasts at the top of the core, but Holes $862 \mathrm{~B}$ and $862 \mathrm{C}$ recovered a series of igneous lithologies to sub-bottom depths of 42.9 and $102.1 \mathrm{~m}$, respectively. Shipboard geochemical data indicate that the Taitao Ridge volcanic rocks have silica contents typical of basalts, dacites, and rhyolites. The basalts are subalkalic to tholeitic, with phenocrysts of olivine, clinopyroxene, and plagioclase; $\mathrm{MgO}$ contents are $8.0-8.6 \mathrm{wt} \%$, and $\mathrm{K}_{2} \mathrm{O}$ values less than $0.5 \mathrm{wt} \%$.

The recovered materials probably represent highly fractured, insitu pillowed flows (Behrmann, Lewis, Musgrave, et al., 1992). All samples have at least some glassy, devitrified, or cryptocrystalline groundmass. The coarsest samples are represented by intersertal to subophitic textures, and none of the basaltic rocks has true ophitic textures typical of the centers of thick flow units or dikes. Thus, a thin or pillowed flow model is generally consistent with estimates of unit thickness and the observed textures.

\section{Taitao Ophiolite}

The Taitao Ophiolite, exposed on the Taitao Peninsula $20 \mathrm{~km}$ east of Site 862 (Fig. 1), was resampled by R. Forsythe in 1992 following Leg 141 in order to supplement the existing suites for a comparative analysis of the alteration mineralogy. Dacites and rare rhyodacites and rhyolites have been reported from the Taitao Ophiolite, together with basalts and basaltic andesites (Forsythe et al., 1986; Kaeding et al., 1990). Radiometric ages from the Taitao Ophiolite are latest Miocene to late Pliocene (Mpodozis et al., 1985). Foraminifers recovered from sediments interbedded with the flows yield Pliocene-Pleistocene ages 


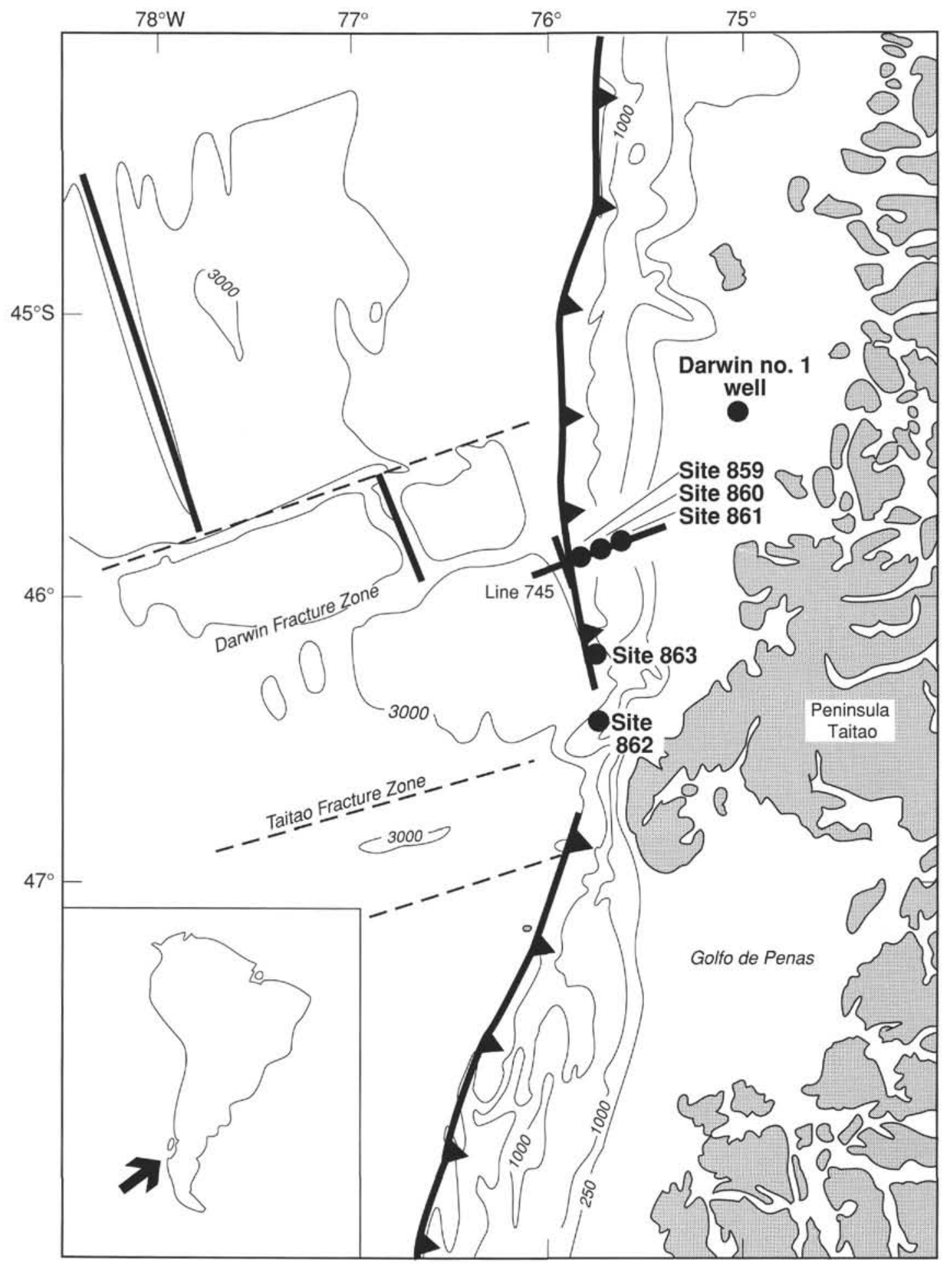

Figure 1. Location map showing the Taitao Ridge (Site 862), the Taitao Fracture Zone, and the Taitao Peninsula with the Taitao Ophiolite. Contour intervals in meters.

(Forsythe et al., 1986). Thus, the probable age of the volcanic basement of the Taitao Ridge overlaps with the age of the Taitao Ophiolite. The petrologic similarities between the ophiolite assemblage and the basement recovered at Site 862, together with the concordance in their ages, suggest that both features are genetically related.

\section{METHODS}

Eleven basaltic samples from Site 862 (Taitao Ridge) and 19 samples from effusive and sheeted-dike complex rocks of the Taitao
Ophiolite were analyzed for major elements by classical wet-chemistry methods and for minor elements by atomic emission methods in the Analytical Center of the Geological Institute, Russian Academy of Sciences. Secondary minerals were studied in thin section, and examined by X-ray diffraction (XRD) in oriented specimens. These oriented specimens were prepared by crushing 1-2-mm-thick pieces with distilled water in an agate mortar to produce suspensions of concentrated clay minerals (pipette methods). Each sample was air-dried, treated with glycerol, and heated at $550^{\circ} \mathrm{C}$ for $1 \mathrm{hr}$. A DRON-3 X-ray diffractometer with $\mathrm{CuK}$ emission, Ni-filter, and slot openings of $0.5,1,1$, 
and $0.5 \mathrm{~mm}$ was used to analyze the specimens. The interpretation of mixed-layer clay minerals was made using the method of Drits et al. (1990). Igneous rocks from both localities were studied in thin section to determine mineralogy and texture; $a$ few samples were examined by scanning electron microscope (SEM). Geochemical data for dacites and rhyolites were adopted from the shipboard results at Site 862 (Behrmann, Lewis, Musgrave, et al., 1992), and from past studies of the Taitao Ophiolite (Kaeding et al., 1990).

\section{PETROGRAPHY}

A brief petrographic description of the samples is given in Tables 1 and 2; results of chemical analyses are presented in Table 3. The results show that the volcanic rocks of the Taitao Ridge are a contrasting, differentiated series. Its main components are basalts, and silicic volcanic rocks that correspond in composition to dacites, rhyodacites, and rhyolites. The succession in which mafic and silicic volcanic rocks erupted cannot be determined from drilling results.

Volcanic rocks of the Taitao Ophiolite complex also represent a complex series dominated by basalts, with subordinate andesitedacites, dacites, and rhyodacites. The sequence of eruption of mafic and silicic volcanic rocks in the ophiolite complex is unclear, as at the Taitao Ridge.

Of the samples examined in this study, the Taitao Ridge basalts are most similar in petrographic composition and texture to those of the ophiolite complex (Tables 1 and 2). Some differences between the two suites are seen, however, in the structure and texture of the incompletely crystallized fine-grained basaltic rocks. The most notable difference is that the basalts of the Taitao Ophiolite are consistently more vesicular than the Taitao Ridge samples, with some exhibiting porosity similar to that of scoria $(>50 \%)$. This suggests that thin flows formed at medium to shallow oceanic depths comparable to those of the continental shelf. Conversely, the Taitao Ridge basalts formed at greater depths than those of the ophiolite complex. In texture, the Taitao Ridge basalts are dominated by finer-grained vitrophyric varieties, with sparse olivine or plagioclase-pyroxene-olivine microphyric basalts. Clinopyroxene is represented by augite, and plagioclase by labradorite and bytownite. The ophiolitic basalts are dominated by plagiophyric and pyroxene-plagiophyric textures. $\mathrm{Cli}$ nopyroxene is represented by $\mathrm{Fe}$-augite and Ti-augite, and plagioclase by andesine and labradorite.

The textures and petrographic composition of the Taitao Ridge basalts suggest that they are poorly differentiated subalkaline oceanic basalts. The greater abundance of olivine and higher An content of plagioclase suggest that some of the Taitao Ridge basalt samples are less evolved than those of the onshore ophiolite. From the variation in phenocryst phases both within and between the two suites, it is clear that the early separation of olivine and the accumulation of plagioclase and clinopyroxene have partly controlled the differentiation of these suites.

\section{GEOCHEMISTRY}

Geochemical results (Table 3) also demonstrate several similarities and differences in the two basalt suites. Most basalts in the two suites fall within the alkaline olivine series of the CIPW system, but the ophiolitic basalts are more alkaline than the Taitao Ridge basalts. About one-half of all of the samples contain normative nepheline. The ophiolitic basalts contain normative nepheline up to $5.95 \%$, but the Taitao Ridge basalts contain only $1.86 \%$ (Table 3 ). However, given the higher alteration within the ophiolite (discussed below), the present alkali contents in these samples are not necessarily representative of the original contents (e.g., spilitization of plagioclase).

In Macdonald's (1968) variation diagram (Fig. 2), silicic samples from both suites plot together within the tholeiitic field. Basaltic samples from the Taitao Ridge plot across the boundary between alkalic and tholeiitic fields, whereas most of the ophiolitic basalts plot in the alkalic field. Basalts from both suites fall within the field of

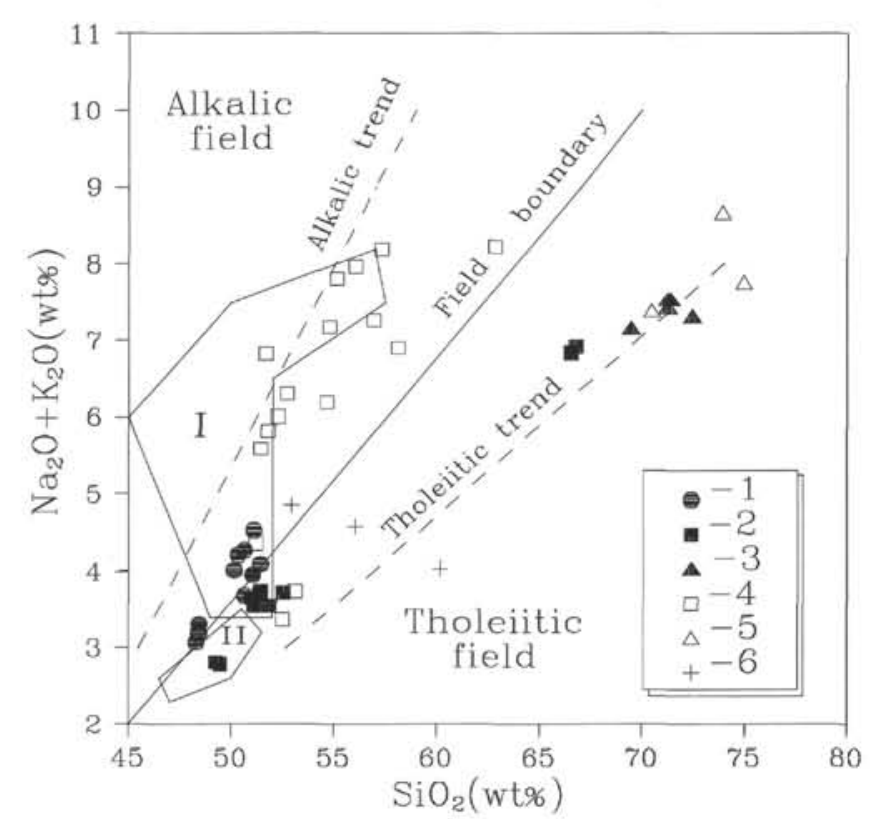

Figure 2. Macdonald's (1968) variation diagram comparing suites from Site 862 on the Taitao Ridge (solid symbols) and the Taitao Ophiolite (open symbols and crosses). Key: $\mathrm{I}$ = field of intraplate alkaline and subalkaline basalts (Perfiljev et al., 1991); II = field of MORB (Perfiljev et al., 1991); I = Site 862 basalts (this work); $2=$ Site 862 , basalts (Kaeding et al., 1990); 3 = Site 862 , silicic rocks (Kaeding et al., 1990); 4 = Taitao Ophiolite, new data on basalts; 5 = Taitao Ophiolite, silicic rocks (Kaeding et al., 1990); 6 = Taitao Ophiolite, new data on dikes. Symbols 1-6 are used also for Figures 3-6.

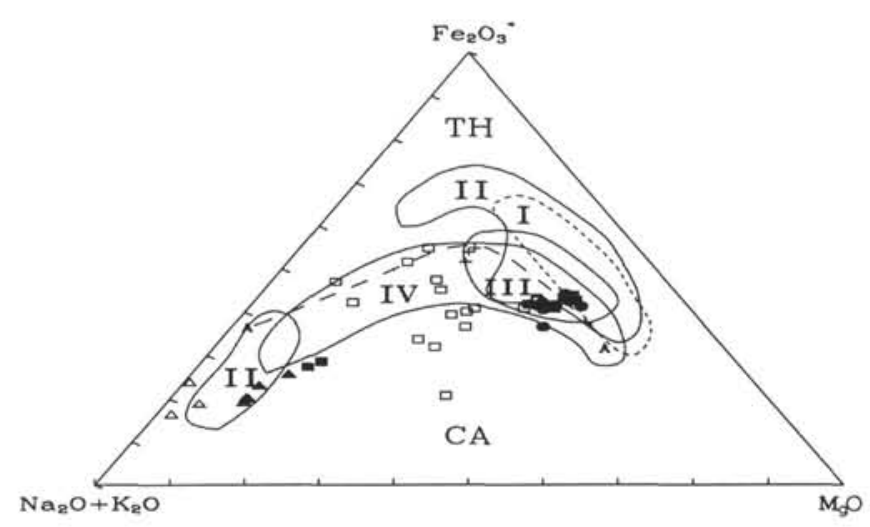

Figure 3. AFM diagram. $\mathrm{I}=$ MORB field; $\mathrm{II}=$ field of contrasting differentiated series of Iceland and Easter Island; III = field of Discovery Rise and Walvis Ridge; IV = field of subalkaline and alkaline basalts of Hawaii, Cocos, and Cape Verde islands. Symbols for sample analyses are the same as for Figure 2.

intraplate subalkalic oceanic basalts, such as those of the Discovery Rise, Walvis Ridge, or Cocos Island (Zolotarev and Kotenev, 1987; Castillo et al., 1988). The differentiation trends are more alkalic for the ophiolite complex and more tholeiitic for the Taitao Ridge suite.

On an AFM diagram (Fig. 3), samples from the Taitao Ridge form two groups, with some samples from the Taitao Ophiolite plotting between them. The two suites together range from the intraplate alkaline field through the field of intraplate subalkaline and alkaline basalts and overlap the fields of MORB and Discovery Rise-Walvis Ridge.

In the two-component variation diagrams for $\mathrm{MgO}-\mathrm{SiO}_{2}, \mathrm{CaO}-$ $\mathrm{SiO}_{2}, \mathrm{Na}_{2} \mathrm{O}-\mathrm{SiO}_{2}$, and $\mathrm{K}_{2} \mathrm{O}-\mathrm{SiO}_{2}$, compositions of the two suites form distinct but interrelated fields in each diagram (Fig. 4). The same subgroups of samples overlap within each of the following intervals of weight $\%: \mathrm{SiO}_{2}=48-51, \mathrm{TiO}_{2}=1.1-1.3$ (not displayed), $\mathrm{CaO}=$ 

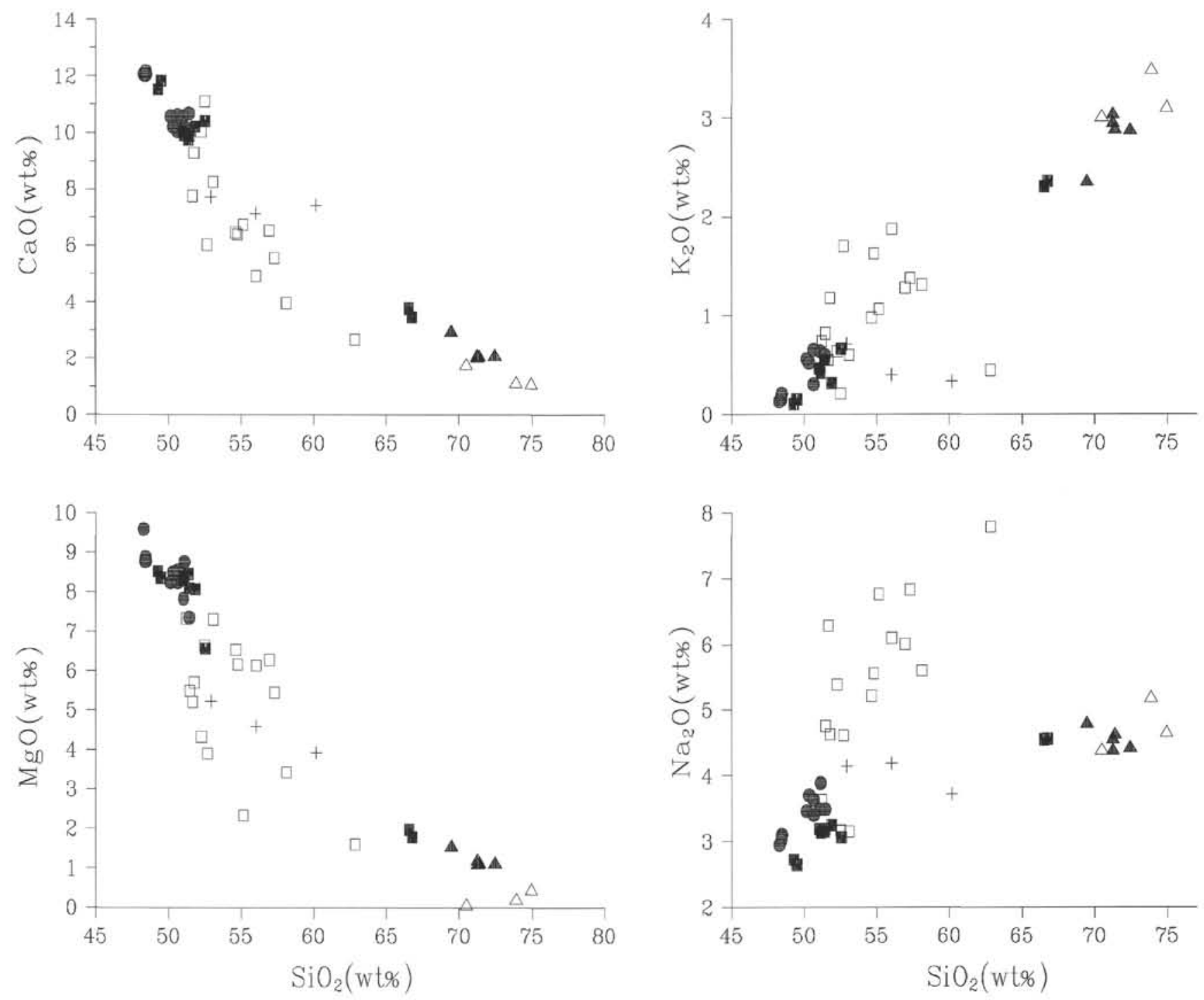

Figure 4. Variation diagrams for major elements. Symbols for sample analyses are the same as for Figure 2.

9.5-10.8, $\mathrm{MgO}=6.0-8.3, \mathrm{Na}_{2} \mathrm{O}=2.8-3.7$, and $\mathrm{K}_{2} \mathrm{O}=0.5-0.8$. In the variation diagrams for $\mathrm{V}-\mathrm{Cr}$, and $\mathrm{Ni}-\mathrm{Cr}$ (Fig. 5), basalts from the two suites form two poorly interrelated fields, with mutually overlapping concentrations, but concentrations for the $\mathrm{V}-\mathrm{Ni}$ diagram form distinctly different fields. The similar concentrations of these major and minor element components for the overlapping subgroups of samples likely represent similarities in the primary melts of the two suites.

Variation diagrams in Figure 6 show the main rock-forming elements $\left(\mathrm{CaO}, \mathrm{Fe}_{2} \mathrm{O}_{3} *, \mathrm{MgO}, \mathrm{Al}_{2} \mathrm{O}_{3}, \mathrm{TiO}_{2}\right.$, and $\left.\mathrm{K}_{2} \mathrm{O}\right)$ and minor elements $(\mathrm{V}, \mathrm{Cr}$, and $\mathrm{Ni}$ ) versus the differentiation index $\mathrm{MG}[\mathrm{MgO} /$ $\left.\left(\mathrm{MgO}+\mathrm{Fe}_{2} \mathrm{O}_{3}{ }^{*}\right)\right]$. Each suite forms two poorly interrelated and partially overlapping fields, and each exhibits different evolutionary paths. The area of overlap within the interval $0.45-0.55 \mathrm{MG}$ presumably corresponds to the composition of the undifferentiated primary melt composition. Excepting the more primitive components from both suites, the more evolved samples do not appear to have shared a common evolutionary path.

\section{ALTERATION}

\section{Taitao Ridge (Site 862)}

The secondary minerals observed in thin section and the XRD analysis of clay fractions extracted from basalts reveal that the rocks are almost fresh, with generally little alteration (Table 1). Two samples of basalt (141-862C-7R-1, 43-45 cm, and 141-862C-8R-1, 71-75 $\mathrm{cm}$ ) contain greater amounts of smectite and are moderately altered. Chemical analyses show 1.30 and $1.17 \mathrm{wt} \% \mathrm{H}_{2} \mathrm{O}^{+}$in these two samples, respectively (Table 3 ). The rest of the samples are almost fresh to weakly altered, with only 0.14 to $0.7 \mathrm{wt} \% \mathrm{H}_{2} \mathrm{O}^{+}$.

The basalts are altered to low concentrations of smectite. On XRD patterns, smectite exhibits about $12.6 \AA$ in air-dried samples, about $17.4-17.8 \AA$ in samples treated with glycerol, and about $9.8 \AA$ after heating. The smectite includes about $25 \%-30 \%$ of an irregularly interlayered mica-type mineral. Smectite mainly replaces groundmass glass and olivine, infills pores and thin cracks, and covers amygdule walls (Table 1). Glass in small interstices is altered to smectite everywhere. Smectite also partially replaces pyroxene and plagioclase. Veins containing smectite are sparsely present (Table 1).

Other clay minerals identified include chlorite, illite, and talc in trace amounts (Table 1). Chlorite is present in Samples 141-862B$4 \mathrm{X}-2,26-30 \mathrm{~cm}, 141-862 \mathrm{~B}-4 \mathrm{X}-2,59-63 \mathrm{~cm}, 141-862 \mathrm{C}-6 \mathrm{R}-1,19-21$ $\mathrm{cm}$, and 141-862C-6R-1, 54-55 cm. Talc is present in Sample 141$862 \mathrm{~B}-4 \mathrm{X}-2,59-63 \mathrm{~cm}$, only. Illite is located in a light-colored vesicle together with smectite, phillipsite, and quartz in Sample 141-862B$2 \mathrm{X}-\mathrm{CC}, 33-38 \mathrm{~cm}$. Glauconite or celadonite is present in the outer part of an amygdule wall in Sample 141-862C-7R-1, 43-45 cm. Iddingsite replacements of olivine are mainly smectite (Samples 141$862 \mathrm{~B}-4 \mathrm{X}-2,26-30 \mathrm{~cm}$, and 141-862C-7R-1, 43-45 cm). 
Table 1. Brief petrographic descriptions of analyzed basalts and secondary minerals, Site 862 (Taitao Ridge).

\begin{tabular}{|c|c|c|}
\hline $\begin{array}{l}\text { Core. section. } \\
\text { interval }(\mathrm{cm})\end{array}$ & $\begin{array}{l}\text { Depth } \\
\text { (mbsf) }\end{array}$ & Description \\
\hline $\begin{array}{l}141-862 B- \\
2 X-C C .33-38\end{array}$ & 21.60 & $\begin{array}{l}\text { Olivine-plagioclase basalt, fine-grained, aphyric, weakly crystallized. Texture of groundmass is subvariolitic and } \\
\text { hyalopilitic. Rare microphenocrysts of high-Fe olivine are joined with plagioclase. Plagioclase (up to } 0.8 \mathrm{~mm} \\
\text { diameter) is labradorite (An } 55 \text { ). Crystalline phase is represented by clinopyroxene. plagioclase, and olivine } \\
\text { (25\% of rock). Groundmass glass is weakly anisotropic with variolitic texture. Varioles are filled by } \\
\text { interpaniculated plagioclase laths. } \\
\text { Alteration: Almost fresh. Smectite weakly replaces part of groundmass glass and olivine. } \\
\text { XRD: Glass of chill zone is fresh. with trace of quartz. Weakly altered basalt contains smectite with about } 25 \% \\
\text { interlayered mica. Traces of phillipsite, quartz, smectite, and illite in a light pellicle covering chilled glass crust. }\end{array}$ \\
\hline $3 X-1.9-13$ & 27.19 & $\begin{array}{l}\text { Pyroxene-olivine-plagioclase hyalobasalt. sparsely microporphyritic, aphanitic. Groundmass has hyalopilitic } \\
\text { texture; subvariolitic texture with microphenocrysts (about } 25 \% \text { of the rock, size is } 0.3-0.8 \mathrm{~mm} \text { ) of olivine, } \\
\text { clinopyroxene, and plagioclase }\left(\mathrm{An}_{50-52}\right) \text {. Some olivines appear to be quench crystals. } \\
\text { Alteration: Almost fresh. } \\
\text { XRD: Glass of chill zone is fresh, with trace of quartz. Basalt is fresh, with quartz as trace. The white thin crust that } \\
\text { covers the chilled glass crust consists of phillipsite and trace of quartz. }\end{array}$ \\
\hline $4 X-2.26-30$ & 37.42 & $\begin{array}{l}\text { Olivine-pyroxene-plagioclase microdolerite, fine-grained, is almost all crystallized, weakly vesicular, with } \\
\text { microdoleritic texture (subtrachytic and intersertal). Plagioclase (up to } 1 \mathrm{~mm} \text { in size) is labradorite-bytownite } \\
\left(\mathrm{An}_{62-71}\right) \text {, pyroxene is Fe-augite. Opaques of magnetite and Ti-magnetite }(0.04 \mathrm{~mm} \text { ) are skeletal crystals } \\
\text { located in an intersertal mass. } \\
\text { Alteration: Low. Smectite replaces groundmass glass and dark-colored minerals; iddingsite replaces olivine. } \\
\text { Numerous vesicles are infilled and encrusted by smectite. } \\
\text { XRD: Smectite with about } 25 \%-30 \% \text { interlayered mica type; chlorite and quartz as trace. }\end{array}$ \\
\hline $4 X-2,59-63$ & 37.75 & $\begin{array}{l}\text { Olivine-pyroxene-plagioclase microdolerite, fine-grained, is almost all crystallized, weakly vesicular. This sample } \\
\text { is same as Sample } 141-862 \mathrm{~B}-4 \mathrm{X}-2,26-30 \mathrm{~cm} \text {. } \\
\text { Alteration: Almost fresh. } \\
\text { XRD; Smectite with about } 25 \%-30 \% \text { mica-type mineral between layers: chlorite, quartz, and talc ( } 9.4 \AA \text { ) as trace. } \\
\text { Low reflex at } 7.3 \mathrm{~A} \text { was not identified, but may be serpentine. }\end{array}$ \\
\hline $\begin{array}{l}141-862 C- \\
\mid W-1,38-39\end{array}$ & 39.38 & $\begin{array}{l}\text { Olivine hyalobasalt is microporphyritic. aphanitic with vitrophyric texture. Idiomorphic olivine phenocrysts }(0.3 \text { to } \\
\qquad \mathrm{mm}) \text { are submerged in isotropic volcanic glass that contains microlites and crystallites of plagioclase and } \\
\text { clinopyroxene. } \\
\text { Alteration: Fresh. } \\
\text { XRD: Very weak elevated line of diffractogram in clay mineral area: quartz as trace. }\end{array}$ \\
\hline $6 R-1,9-12$ & 74.59 & $\begin{array}{l}\text { Olivine-plagioclase microdolerite, porphyritic and almost all crystallized, with microdoleritic texture (interstitial). } \\
\text { Phenocrysts are about } 15 \% \text { of the rock. Olivine (up to } 1 \mathrm{~mm} \text { ) predominates among phenocrysts. Plagioclase } \\
\text { (labradorite. } \mathrm{An}_{56} \text { ) is represented by tabular and idiomorphic phenocrysts up to } 1 \mathrm{~mm} \text { in size. Nonoriented } \\
\left.\text { aggregates of plagioclase laths (labradorite, } \mathrm{An}_{52-60}\right) \text {, augite grains with very small magnetite crystals, and } \\
\text { brownish-green glass comprise the groundmass. } \\
\text { Alteration: Low. Smectite replaces groundmass glass. } \\
\text { XRD: Smectite with about } 25 \% \text { mica between layers; quart/ as trace. }\end{array}$ \\
\hline $6 \mathrm{R}-1.19-21$ & 74.69 & $\begin{array}{l}\text { Plagioclase-olivine basalt, microporphyritic, fine-grained, weakly crystallized, with hyalopilitic and pilotaxitic } \\
\text { textures, Olivine forms small idiomorphic crystals }(0.2-0.4 \mathrm{~mm} \text { ), many combined with plagioclase (labradorite } \\
\text { An } 58 \text { ) laths. Plagioclase is up to } 2 \mathrm{~mm} \text { in size. Phenocrysts are about } 10 \%-15 \% \text { of the rock. Groundmass glass is } \\
\text { partly crystallized with formation of sheaf-like aggregates and crystallites of clinopyroxene and plagioclase. } \\
\text { Alteration: Almost fresh. Smectite partially replaces groundmass glass and olivine. } \\
\text { XRD: Smectite with about } 25 \% \text { mica between layers: chlorite and quartz as trace. }\end{array}$ \\
\hline $6 \mathrm{R}-1.54-55$ & 75.04 & $\begin{array}{l}\text { Olivine basalt, fine-grained, aphyric weakly vesicular with hyaline (vitrophyric) texture. Single quench crystals of } \\
\text { olivine are submerged in weakly anisotropic volcanic glass. Sparse vesicles are to } 0.2 \mathrm{~mm} \text {. } \\
\text { Alteration: Almost fresh. The groundmass glass is partially replaced by rare quartz and carbonate. } \\
\text { XRD: Basalt is fresh. with traces of quartz and chlorite. }\end{array}$ \\
\hline $7 R-1,43-45$ & 83.83 & $\begin{array}{l}\text { Olivine basalt, sparsely porphyritic, fine-grained. with hyalopilitic (some parts with subvariolitic) texture. Olivine } \\
\text { (up to } 0.5 \mathrm{~mm} \text { ) is represented by isomorphic crystals. Microphenocrysts are about } 5 \% \text { of the rock. Groundmass } \\
\text { consists of fan-shaped, needle-shaped, skeletal plagioclase microlites and aggregates of small clinopyroxene } \\
\text { crystals that are submerged in volcanic glass. } \\
\text { Alteration: Moderate. Smectite partially replaces groundmass glass. Olivine is replaced by iddingsite. Rare pores } \\
\text { are filled by carbonate and smectite with carbonate in the central part of the pores. } \\
\text { XRD: Smectite with about } 25 \%-30 \% \text { mica type between layers; quartz as trace. Large vesicle (about } 0.5 \mathrm{~cm} \\
\text { diameter) contains illite with about } 20 \% \text { swelling layers, of possibly glauconite or celadonite. Smectite as trace. } \\
\text { White mineral in vesicle fill is aragonite. }\end{array}$ \\
\hline $8 R-1.52-53$ & 93.62 & $\begin{array}{l}\text { Olivine basalt, sparsely porphyritic, fine-grained vesicular texture with hyalopilitic (to subvariolitic) groundmass. } \\
\text { Microphenocrysts of olivine are up to } 1 \% \text { of the rock. Groundmass is represented by olivine, plagioclase, and } \\
\text { clinopyroxene microlites that are submerged in weakly isotropic glass. Quench crystals are observed among } \\
\text { olivines. Vesicles are about } 15 \% \text { of the rock }(0.01 \text { to } 2 \mathrm{~mm} \text { ). } \\
\text { Alteration: Almost fresh. Possible smectite weakly replaces groundmass glass. Sparse vesicles are filled by } \\
\text { mica-like mineral and carbonate. } \\
\text { XRD: Smectite, quartz, } 7.6 \AA \text { mineral, and } 5.1 \text { A mineral (unidentified) as trace. }\end{array}$ \\
\hline $8 R-1.71-75$ & 93.81 & $\begin{array}{l}\text { Olivine microdolerite. fine grained with single olivine microphenocrysts. with microdoleritic (to subtrachytic) } \\
\text { texture. Plagioclase is presented by nonoriented laths (up to } 1.5 \mathrm{~mm} \text { ), some have subparallel orientation. } \\
\text { Pyroxene is augite }(0.05 \mathrm{~mm} \text { ). Magnetite is about } 1 \% \text { of the rock. } \\
\text { Alteration: Moderate. About } 15 \% \text { of rock is smectitized, replacing groundmass glass. } \\
\text { XRD: Smectite with about } 25 \% \text { mica type between layers: quartz as trace. }\end{array}$ \\
\hline
\end{tabular}


Table 2. Brief petrographic descriptions of analyzed effusives and sheeted-dike complex of Taitao ophiolite (Taitao Peninsula).

\begin{tabular}{|c|c|}
\hline Sample & Description \\
\hline TT-24-6 & $\begin{array}{l}\text { I. EFFUSIVES } \\
\text { Microdolerite, fine-grained aphyric, weakly vesicular, with microdoleritic-interstitial texture. Plagioclase (labradorite, An } \\
\text { by nonoriented laths }(0.3-0.5 \mathrm{~mm} \text { ). Clinopyroxene (augite) is located among the plagioclase laths. Interstitial glass is weakly } \\
\text { anisotropic, Opaque minerals are represented by magnetite or Ti-magnetite (about } 3 \%-5 \% \text { of the rock). } \\
\text { Alteration: Moderate. Chlorite replaces groundmass glass and partially replaces plagioclase and pyroxene. Vesicles are infilled by chlorite } \\
\text { and carbonate. } \\
\text { XRD: Mixed-layer chlorite-vermiculite mineral: chlorite as trace. }\end{array}$ \\
\hline TT-26-1 & $\begin{array}{l}\text { Plagioclase-pyroxene basalt, fine-grained aphyric, with hyalopilitic texture. Single microphenocrysts }(0.2 \mathrm{~mm}) \text { are represented by } \\
\text { plagioclase and clinopyroxene (augite). Groundmass contains nonoriented microlites of plagioclase that are submerged in volcanic } \\
\text { glass. } \\
\text { Alteration: Strong. Smectite replaces groundmass glass, plagioclase, and dark-colored minerals. } \\
\text { XRD: Smectite is trioctahedral (saponite) with } 15 \%-20 \% \text { of mica between layers (smectite with Na in between layers, } 12.6 \AA \text {. is more than } \\
\text { smeetite with } \mathrm{Ca}-\mathrm{Mg} .14 \mathrm{~A} \text { ). Talc as trace mineral. }\end{array}$ \\
\hline
\end{tabular}

TT-26-4 Pyroxene-plagioclase basalt. fine-grained porphyritic, vesicular. with hyalopilitic texture. Phenocrysts (20\% of the rock) are represented by tabular plagioclase (up to $2-4 \mathrm{~mm}$ ) and idiomorphic crystals of augite $(0.1-0.5 \mathrm{~mm}$ ). Groundmass is represented by plagioclase laths and panicle-like clinopyroxene microlites that are submerged in weakly anisotropic voleanic glass.

Alteration: Strong. Smectite replaces groundmass glass, plagioclase, and dark-colored minerals. Vesicles are filled with smectite and zeolite.

XRD: Smectite is identical to smectite from Sample TT-26-1: analcime as trace.

TT-27-1 Pyroxene-plagioclase basalt, fine-grained porphyritic, weakly vesicular, with hyalopilitic texture, Basalt is same as Sample TT-26-4, but less well crystallized. Glass predominates in groundmass.

Alteration: Strong. Chlorite replaces groundmass glass: chlorite and quartz in veinlets.
XRD: Mixed-layer smectite-chlorite mineral with variable amounts of smectite between layers and different layer charges.

TT-29-4R Pyroxene-plagioclase basalt, fine-grained porphyritic,irregularly vesicular, with hyalopilitic texture. Phenocrysts of tabular plagioclase (up to $3 \mathrm{~mm}$ ) form glomerophyric aggregates with small idiomorphic grains of clinopyroxene (Ca-augite). Groundmass is represented by plagioclase microlites that are submerged in weakly isotropic glass.

Alteration: Strong. Smectite replaces groundmass glass, plagioclase, and dark-colored minerals, Vesicles are filled with smectite.

XRD: Smectite with about $10 \%$ mica between layers; quartz as trace.

TT-29-9R Pyroxene-plagioclase microdolerite. sparsely porphyritic. fine-grained. with doleritic interstitial texture. Plagioclase (andesine. An $40-42$ ) and clinopyroxene ( $\mathrm{Ti}$-augite) form nonoriented laths $(0.5-0.7 \mathrm{~mm})$. Glass and small grains of Ti-augite fill interstices; Ti-magnetite is about $5 \%-7 \%$ of the rock.

Alteration: Moderate. Smectite replaces groundmass glass and dark-colored minerals and partially replaces plagioclase.

XRD: Smectite with about $10 \%-15 \%$ mica between layers; talc. quartz, and illite as trace.

TT-29-5C Basalt, fine-grained plagiophyric, weakly and irregularly vesicular with microdoleritic texture. Phenocrysts are represented by plagioclase (up to $2 \mathrm{~mm}$ ) and single microphenocrysts $(0.4 \mathrm{~mm}$ ) of clinopyroxene (Ca-augite). Plagioclase, clinopyroxene, and glass (approximately in equal quantities) are groundmass. Glass in micropores is commonly replaced by clay minerals.

Alteration: Strong. Smectite replaces groundmass glass and plagioclase. Vesicles are filled by smectite of two types: with thin scaly structure and with radial structure that is located in the centers of vesicles.

XRD: Smectite (possibly Fe-smectite); quartz as trace.

TT-29-11-2 Basalt, fine-grained plagiophyric, vesicular with pilotaxitic texture. This basalt is very similar to basalt of Sample TT-29-5C. Glass is about $50 \%$ of groundmass.

Alteration: Strong. Chlorite replaces groundmass glass and partially replaces plagioclase and dark-colored minerals. Vesicles are infilled by radial chlorite.

XRD: Mixed-layer smectite-chlorite mineral is similar to clay mineral of Sample TT-27-1; analcime as trace.

TT-29-11-3 Pyroxene-plagioclase microdolerite, fine-grained porphyritic with interstitial texture. Phenocrysts are represented by tabular crystals (up to $2 \mathrm{~mm}$ ) of plagioclase (andesine. $\mathrm{An}_{45}$ ) which form glomeroporphyritic aggregates with augite (up to $0.5 \mathrm{~mm}$ ). Groundmass is represented by nonoriented plagioclase $\left(\mathrm{An}_{38}\right)$ laths. Interstices are filled with clinopyroxene. glass, and rare grains of $\mathrm{Ti}$-magnetite. Alteration: Moderate. Smectite replaces groundmass glass and partially replaces plagioclase and dark-colored minerals.

XRD: Smectite with about $15 \%$ mica. Na, and Cal-Mg betweenlayers: quartz as trace.

TT-30-3 Basalt. fine-grained plagiophyric, weakly vesicular, with hyalopilitic texture. Tabular phenocrysts of plagioclase are represented by labradorite $\left(A n_{52}\right)$. Groundmass consists of weakly anisotropic glass. Rare laths and microlites of andesine $\left(A n_{48}\right)$ are submerged in groundmass glass.

Alteration: Strong. Smectite replaces groundmass glass, partially replaces plagioclase, and fills vesicles.

XRD: Smectite with about $15 \%$ mica between layers.

TT-30-5 Pyroxene-plagioclase microdolerite, fine-grained, almost completely crystallized, with microphyric-intersertal texture, Phenocrysts are represented mainly by tabular crystals of plagioclase (up to $1 \mathrm{~mm}$ ). Plagioclase is zoned: interior zones are represented by andesine $\left(A n_{42}\right)$. outside zones by andesine $\left(A n_{32}\right)$. Groundmass consists of aggregates of nonoriented laths of plagioclase (up to 0.5 mm). grains of clinopyroxene (augite). Ti-magnetite (about $1 \%-2 \%$ of the rock), and interstitial glass.

Alteration: Moderate. Smectite replaces groundmass glass, and partially replaces plagioclase and dark-colored minerals.

Alteration: Moderate. Smectite replaces groundmass glass.
XRD: Smectite with about $10 \%-15 \%$ mica between layers.

TT-31-1b Plagioclase-pyroxene basalt. fine-grained porphyritic, weakly crystallized, strongly vesicular, with pilotaxitic texture. Phenocrysts are represented by small grains (up to $0.4 \mathrm{~mm}$ ) of augite and tabular crystals of plagioclase (up to $0.7 \mathrm{~mm}$ ). Some form glomeroporphyritic aggregates. Phenocrysts are about $10 \%-15 \%$ of the rock. Groundmass consists of glass (about $50 \%$ of the rock), laths, and microlites of plagioclase and pyroxene,

Alteration: Strong. Chlorite replaces groundmass glass and partially replaces plagioclase. Vesicles are filled with chlorite, zeolite. and carbonate.

XRD: Mixed-layer smectite-chlorite mineral is similar to clay mineral from Sample TT-27-1: chlorite and analcime as trace.

TT-3I-6a Microdolerite, fine-grained aphyric, is almost all crystallized, vesicular, with microdoleritic- intersertal texture. The rock consists of nonoriented laths (up to $1 \mathrm{~mm}$ ) of plagioclase, isomorphic grains of augite (up to $0.1 \mathrm{~mm}$ ), and weakly anisotropic interstitial glass. Ti-magnetite comprises about $2 \%$ of the rock and is associated with clinopyroxene and glass.

Alteration: Strong. Chlorite replaces groundmass glass anci partially replaces plagioclase. Chlorite and smectite fill vesicles: in the center as needle-shaped clay minerals and in the outer parts as rosette-shaped clay minerals.

XRD: Corrensite and smectite; chlorite as trace.

TT-32-2 Basalt, fine-grained aphyric. incompletely crystallized. weakly vesicular, with hyalopilitic texture. The rock consists of nonoriented microlites of plagioclase (up to $0.1 \mathrm{~mm}$ ), clinopyroxene, and idiomorphic Ti-augite grains. Glasscomprises about $20 \%$ of the rock.

Alteration: Strong. Chlorite replaces groundmass glass and partially replaces plagioclase and dark-colored minerals. Vesicles are partially filled with chlorite and smectite. Quartz is in some vesicles and microcracks. 
Table 2 (continued).

\begin{tabular}{|c|c|}
\hline Sample & Description \\
\hline & XRD: Chlorite and smectite; minor mixed-layer vermiculite-chlorite mineral; and quartz as trace. \\
\hline TT-32-6 & $\begin{array}{l}\text { Basalt, aphyric. almost not crystallized. strongly vesicular. The rock consists of black isotropic or weakly anisotropic glass with micropores } \\
\text { (up to } 50 \% \text { of the rock). } \\
\text { Alteration: Moderate. Chlorite-like mineral with needle-shaped. sheet-like, and panicled structures fills vesicles. } \\
\text { XRD: Mixed-layer smectite-mica mineral with about } 40 \% \text { mica between layers and a mixed-layer chlorite-vermiculite mineral. Chlorite is } \\
\text { minor. Quartz as trace. }\end{array}$ \\
\hline TT-34-9 & $\begin{array}{l}\text { Basalt, fine-grained aphyric, weakly crystallized, strongly vesicular, with vitrophyric (hyaline) texture. An isotropic glass is enriched by } \\
\text { crystals of plagioclase, clinopyroxene, and opaque minerals. Size of vesicles is up to } 0.5 \mathrm{~mm} \text {. } \\
\text { Alteration: Low. Smectite replaces groundmass glass, partially replaces clinopyroxene and plagioclase, and fills vesicles. } \\
\text { XRD: Smectite (saponite): mixed-layer smectite-chlorite mineral is minor; chlorite as trace. }\end{array}$ \\
\hline TT-34-11 & $\begin{array}{l}\text { Lithic-crystal tuff, fine-grained, angular fragments }(0.2-0.3 \mathrm{~mm}) \text { of plagioclase, quartz, quartzite, and altered basalt. Matrix is } \\
\text { cryptocrystalline mixture of mica-like and chlorite-like minerals. } \\
\text { XRD: Chlorite, with mica of muscovite type; quartz and feldspar as minor components. }\end{array}$ \\
\hline $33-5$ & $\begin{array}{l}\text { II. SHEETED-DIKE COMPLEX } \\
\text { Andesitic basalt. fine-grained aphyric, weakly crystallized with microlitic texture. The rock consists of nonoriented microlites of } \\
\text { plagioclase }\left(0.1-0.2 \mathrm{~mm} \text { ), amphibole (actinolite, } \mathrm{Ng} \text {-green, } \mathrm{Np} \text {-greenish yellow, } \mathrm{C:Ng}=15^{\circ} \text { ), and isomorphous grains of augite that are }\right. \\
\text { submerged in volcanic glass. Amphiboles (about } 50 \% \text { of the rock) replace glass. } \\
\text { Alteration: Moderate. Smectite and amphibole replace plagioclase and glass. Microcracks are filled with chalcedony. } \\
\text { XRD: Amphibole: smectite as trace. }\end{array}$ \\
\hline 33-9 & $\begin{array}{l}\text { Microdolerite, fine-grained aphyric. almost all crystallized (congodolerite), with microdoleritic texture. The rock consists of nonoriented } \\
\text { laths of plagioclase (up to } 0.6 \mathrm{~mm} \text { ), isomorphous grains of clinopyroxene (augite), and minor amounts of amphibole (actinolite). In } \\
\text { interstices between microlites of plagioclase and amphibole are minor amounts of quartz. Opaque minerals areabout } 5 \% \text { of the rock. } \\
\text { Alteration: Moderate. Chlorite and smectite replace plagioclase and pyroxene. Low-temperature amphibole partially replaces } \\
\text { clinopyroxene and primary amphibole. } \\
\text { XRD: Chlorite, smectite, and amphibole; quartz as trace mineral. }\end{array}$ \\
\hline $33-10$ & $\begin{array}{l}\text { Plagioclase-amphibole microdolerite, fine-grained aphyric, crystallized with intergranular texture. The rock consists of nonoriented laths of } \\
\text { plagioclase (up to } 0.5 \mathrm{~mm} \text { ) and prismatic. radial-radiant grains of amphibole (actinolite series). Ti-magnetite comprises } 3 \%-5 \% \text { of the } \\
\text { rock. There are single grains of quartz. Opaque minerals are about } 5 \% \text { of the rock. } \\
\text { Alteration: Strong. Primary amphibole is replaced by low-temperature amphibole with grassy-green color. Plagioclase is replaced by } \\
\text { chlorite and smectite. } \\
\text { XRD: Chlorite and amphibole; smectite is minor: quartz as trace. }\end{array}$ \\
\hline
\end{tabular}

Nonclay alteration minerals are quartz, phillipsite, and carbonate (aragonite). Quartz is present almost in all samples as trace and secondary minerals. Phillipsite, together with smectite, illite, and quartz, is present in a thin light crust that covers chilled glass in Samples 141862B-2X-CC, $33-38 \mathrm{~cm}$, and 141-862B-3X-1, 9-13 cm. Together with smectite, carbonate infills the central parts of sparse pores. In Sample 141-862C-7R-1, 43-45 cm, this carbonate was identified as aragonite. Some carbonate replaces groundmass glass in Sample 141$862 \mathrm{C}-6 \mathrm{R}-1,54-55 \mathrm{~cm}$. Minerals with reflexes at 5.1 and $7.6 \AA$ (Sample 141-862C-8R-1, 52-53 cm) and 7.3 Å (Sample 141-862B-4X-2, $59-63 \mathrm{~cm}$ ) were not identified.

\section{Taitao Ophiolite}

The effusives and sheeted-dike complex rocks of the Taitao Ophiolite are much more altered than rocks from the Taitao Ridge (Tables 2 and 3). Only one sample of basalt (TT-34-9) is weakly altered $\left(\mathrm{H}_{2} \mathrm{O}^{+} 0.62 \mathrm{wt} \%\right)$. All basalts from the effusive part of the Taitao Ophiolite are strongly altered $\left(\mathrm{H}_{2} \mathrm{O}^{+}\right.$approximately $2 \mathrm{wt} \%$ to $3.66 \mathrm{wt} \%)$, except for Sample TT-32-6, which is only moderately altered $\left(\mathrm{H}_{2} \mathrm{O}^{+} 1.69 \mathrm{wt} \%\right)$. Four samples of microdolerites (TT-24-6, TT-29-9R, TT-29-11-3, and TT-30-5) are moderately altered $\left(\mathrm{H}_{2} \mathrm{O}^{+}\right.$ from 1.38 to $1.89 \mathrm{wt} \%$ ).

Principal secondary minerals in these rocks are smectite or mixedlayer smectite-chlorite, chlorite-vermiculite, and smectite-mica minerals. These minerals replace groundmass glass, plagioclase, and darkcolored minerals, as well as fill vesicles and thin cracks (Table 2). Smectites are the major alteration minerals for one-half the samples of effusives (Table 2), both in basalts (Samples TT-26-1, TT-26-4, TT-294R, TT-29-5C, TT-30-3, and TT-34-9) and in microdolerites (Samples TT-29-9R, TT-29-11-3, and TT-30-5).

Smectites vary from high-charge smectite (saponite) in Sample TT-34-9 to possibly Fe-smectite in Sample TT-29-5C. Smectite with about $10 \%$ mica between layers occurs in Sample TT-29-4R. Samples TT-29-9R, TT-30-3, and TT-30-5 contain smectite with about $15 \%$ mica between layers. Heterogeneous smectite with $\mathrm{Na}(12.6 \AA)$ and
Ca-Mg (14 $\AA$ ) between the layers occurs in Samples TT-29-11-3, TT-26-1, and TT-26-4.

The predominance of mixed-layer minerals is widespread in the effusives of the Taitao Ophiolite (Table 2). They are present in both basalts (Samples TT-27-1, TT-29-11-2, TT-31-1b, and TT-32-6) and microdolerites (Samples TT-24-6 and TT-31-6a). Mixed-layer micasmectite minerals (mica layers are about $40 \%$ ) and minor amounts of heterogeneous mixed-layer chlorite-vermiculite are found in Sample TT-32-6. Corrensite was determined in Sample TT-31-6a. Mixedlayer smectite-chlorite with a different amount of swelling between layers and a different layer charge occurs as the predominant mineral in Samples TT-27-1, TT-31-1b, and TT-29-11-2. Mixed-layer chlorite-vermiculite with a trace of chlorite was found in Sample TT-24-6. In one sample of basalt (TT-32-2) a predomination of chlorite with smectite was observed. Tuff (Sample TT-34-11) also contains a high content of chlorite. Besides the principal clay minerals, chlorite, illite, talc, quartz, analcime, and carbonate in minor and trace amounts (Table 2) are also present in the ophiolitic effusives.

Rocks of the sheeted-dike complex are altered moderately to strongly $\left(\mathrm{H}_{2} \mathrm{O}^{+} 1.12\right.$ to $\left.2.14 \mathrm{wt} \%\right)$. Chlorite and amphibole are principal secondary minerals for these rocks (Table 2). Smectite in minor and trace amounts and quartz in trace amounts are also present.

\section{DISCUSSION}

The petrographic and geochemical data suggest that in each suite, basalts and silicic volcanic rocks are comagmatic and may have been derived from subalkaline primary melts of similar composition. The question is: to which oceanic tectono-magmatic types should these volcanic rocks be compared? The hypothetical primary melts share some features with those of mid-oceanic ridge tholeiitic basalts as well as intraplate rise alkaline basalts, but differ in several parameters. Oceanic fracture zones are characterized by tholeiitic and alkaline magmatism of their own. Melson et al. (1967), Natland and Melson (1980), Thompson and Melson (1972), and others have described alkaline olivine basalts along with tholeiites in the Saint Paul Fracture 
Table 3. Composition and normative mineralogy of igneous rocks from Site 862 (Taitao Ridge) and the Taitao Ophiolite (Taitao Peninsula).

\begin{tabular}{|c|c|c|c|c|c|c|c|c|c|c|c|c|c|c|c|c|}
\hline Sample no.: & 1 & 2 & 3 & 4 & 5 & 6 & 7 & 8 & 9 & 10 & 11 & 12 & 13 & 14 & 15 & 16 \\
\hline \multicolumn{17}{|c|}{ Major elements (wt\%) } \\
\hline $\mathrm{SiO}_{2}$ & 48.20 & 49.57 & 49.54 & 51.09 & 47.87 & 48.30 & 50.92 & 49.41 & 47.81 & 49.59 & 49.76 & 53.66 & 54.21 & 49.41 & 52.61 & 49.96 \\
\hline $\mathrm{TiO}_{2}^{-}$ & 1.02 & 1.28 & 1.36 & 1.10 & 1.02 & 1.11 & 1.02 & 1.19 & 1.02 & 1.28 & 1.20 & 1.78 & 0.93 & 1.28 & 1.28 & 1.15 \\
\hline $\mathrm{Al}_{2} \mathrm{O}_{3}$ & 17.37 & 16.43 & 16.50 & 17.24 & 17.30 & 17.20 & 17.03 & 16.50 & 17.52 & 16.90 & 16.47 & 17.86 & 17.58 & 16.52 & 15.55 & 18.87 \\
\hline $\mathrm{Fe}_{2} \mathrm{O}_{3}$ & 3.82 & 4.57 & 4.56 & 3.11 & 2.43 & 3.91 & 1.10 & 4.97 & 2.81 & 3.39 & 4.80 & 5.12 & 1.63 & 5.12 & 4.20 & 3.34 \\
\hline $\mathrm{FeO}$ & 4.78 & 3.71 & 3.63 & 4.59 & 5.78 & 5.10 & 5,91 & 2.85 & 5.39 & 4.94 & 3,37 & 1.94 & 1.58 & 3.97 & 3.86 & 2.79 \\
\hline $\mathrm{MnO}$ & 0.13 & 0.12 & 0.11 & 0.11 & 0.12 & 0.11 & 0.11 & 0.10 & 0.13 & 0.13 & 0.10 & 0.21 & 0.05 & 0.17 & 0.12 & 0.13 \\
\hline $\mathrm{MgO}$ & 8.74 & 8.05 & 8.37 & 7.30 & 9.50 & 8.76 & 8.73 & 7.58 & 8.75 & 8.14 & 8.39 & 2.28 & 5.97 & 4.99 & 6.30 & 5.50 \\
\hline $\mathrm{CaO}$ & 12.01 & 9.83 & 10.05 & 10.60 & 11.98 & 12.03 & 10.19 & 10.25 & 12.03 & 10.45 & 10.42 & 6.54 & 6.20 & 7.42 & 6.21 & 8.94 \\
\hline $\mathrm{Na}_{2} \mathrm{O}$ & 3.08 & 3.54 & 3.63 & 3.46 & 2.91 & 3.00 & 3.88 & 3.38 & 3.00 & 3.42 & 3.33 & 6.57 & 5.70 & 6.00 & 5.02 & 4.47 \\
\hline $\mathrm{K}, \mathrm{O}$ & 0.21 & 0.64 & 0.51 & 0.60 & 0.13 & 0.18 & 0.63 & 0.44 & 0.15 & 0.55 & 0.29 & 1.03 & 1.22 & 0.53 & 0.94 & 1.14 \\
\hline $\mathrm{P}_{2} \mathrm{O}_{6}$ & 0.12 & 0.15 & 0.17 & 0.15 & 0.09 & 0.08 & 0.10 & 0.13 & 0.08 & 0.13 & 0.14 & 0.31 & 0.13 & 0.19 & 0.19 & 0.17 \\
\hline $\mathrm{H}_{2} \mathrm{O}^{-}$ & 0.37 & 1.27 & 0.74 & 0.43 & 0.46 & 0.47 & 0.21 & 2.14 & 0.38 & 0.61 & 1.01 & 0.45 & 1.92 & 1.12 & 1.25 & 0.99 \\
\hline $\mathrm{H}_{2} \mathrm{O}^{+}$ & 0.14 & 0.52 & 0.36 & 0.33 & 0.70 & 0.23 & 0.64 & 1.30 & 0.58 & 0.24 & 1.17 & 1.88 & 1.97 & 3.08 & 2.05 & 2.45 \\
\hline $\mathrm{CO}_{2}$ & 0.50 & 0.75 & 0.45 & - & - & - & - & - & - & - & - & - & 0.60 & 0.6 & - & - \\
\hline Total & 100.49 & 100.43 & 99.98 & 100.11 & 100.29 & 100,48 & 100.47 & 100.24 & 99.65 & 99.77 & 100.45 & 99.69 & 99.69 & 100.40 & 99.58 & 99.90 \\
\hline \multicolumn{17}{|c|}{ Trace elements (ppm) } \\
\hline V & 210 & 190 & 180 & 260 & 260 & 250 & 180 & 215 & 180 & 220 & 200 & 275 & 210 & 180 & 195 & 210 \\
\hline $\mathrm{Cr}$ & 310 & 220 & 290 & 460 & 500 & 400 & 280 & 320 & 190 & 300 & 320 & 44 & 190 & 115 & 160 & 210 \\
\hline $\mathrm{Ni}$ & 160 & 170 & 175 & 190 & 240 & 185 & 175 & 200 & 140 & 160 & 250 & 25 & 90 & 55 & 58 & 80 \\
\hline \multicolumn{17}{|l|}{ CIPW norms } \\
\hline Quartz & 0.00 & 0.00 & 0.00 & 0.00 & 0.00 & 0.00 & 0.00 & 0.00 & 0.00 & 0.00 & 0.00 & 0.00 & 0.00 & 0.00 & 0.00 & 0.00 \\
\hline Orthoclase & 1.25 & 3.86 & 3.06 & 3.57 & 0.78 & 1.07 & 3.74 & 2.69 & 0.90 & 3.29 & 1.74 & 6.26 & 7.57 & 3.28 & 5.77 & 6.99 \\
\hline Albite & 24.96 & 30.59 & 31.20 & 29.46 & 22.76 & 25.25 & 29.52 & 29.54 & 23.66 & 29.26 & 28.67 & 53.15 & 50.65 & 42.12 & 44.11 & 35.42 \\
\hline Anorthite & 33.14 & 27.65 & 27.67 & 29.95 & 34.07 & 33.02 & 27.31 & 29.51 & 34.36 & 29.48 & 29.66 & 16.67 & 19.74 & 17.36 & 17.80 & 29.10 \\
\hline Nepheline & 0.67 & 0.00 & 0.00 & 0.00 & 1.12 & 0.10 & 1.86 & 0.00 & 1.11 & 0.00 & 0.00 & 2.15 & 0.00 & 5.95 & 0.00 & 2.05 \\
\hline Diopside & 20.59 & 16.58 & 17.09 & 17.50 & 20.23 & 20.83 & 18.32 & 17.24 & 20.43 & 17.55 & 17.17 & 11.36 & 9.10 & 15.61 & 10.17 & 12,31 \\
\hline Hypersthene & 0.00 & 0.00 & 0.00 & 0.00 & 0.00 & 0.00 & 0.00 & 0.00 & 0.00 & 0.00 & 0.00 & 0.00 & 0.00 & 0.00 & 0.00 & 0.00 \\
\hline Olivine & 11.63 & 24.77 & 26.49 & 24.59 & 15.35 & 11.75 & 15.49 & 16.55 & 13.28 & 33.41 & 20.81 & 0.40 & 23.66 & 4.94 & 19.88 & 6.47 \\
\hline Magnetite & 5.57 & 6.77 & 6.72 & 4.54 & 3.55 & 5.68 & 1.60 & 6.25 & 4.13 & 4,97 & 7.08 & 1.82 & 2.48 & 7.77 & 6.33 & 5.02 \\
\hline Ilmenite & 1.95 & 2.48 & 2.62 & 2.10 & 1.95 & 2.11 & 1.94 & 2.33 & 1.96 & 2.42 & 2.32 & 3.47 & 1.86 & 2.54 & 2.52 & 2.26 \\
\hline Hematite & 0.00 & 0.00 & 0.00 & 0.00 & 0.00 & 0.00 & 0.00 & 0.00 & 0.00 & 0.00 & 0.00 & 4.01 & 0.00 & 0.00 & 0.00 & 0.00 \\
\hline Apatite & 0.28 & 0.35 & 0.40 & 0.35 & 0.21 & 0.19 & 0.23 & 0.31 & 0.19 & 0.30 & 0.33 & 0.74 & 0.32 & 0.46 & 0.46 & 0.41 \\
\hline
\end{tabular}

Note: Samples as follows: $1=141-862 \mathrm{~B}-2 \mathrm{X}-\mathrm{CC} .33-38 \mathrm{~cm} ; 2=141-862 \mathrm{~B}-4 \mathrm{X}-2.26-30 \mathrm{~cm}: 3=141-862 \mathrm{~B}-4 \mathrm{X}-2.59-63 \mathrm{~cm} ; 4=141-862 \mathrm{C}-1 \mathrm{~W}-1,38-39 \mathrm{~cm}: 5=141-862 \mathrm{C}-6 \mathrm{R}-1,9-$ $12 \mathrm{~cm}: 6=141-862 \mathrm{C}-6 \mathrm{R}-1.19-21 \mathrm{~cm}: 7=141-862 \mathrm{C}-6 \mathrm{R}-1.54-55 \mathrm{~cm}: 8=141-862 \mathrm{C}-7 \mathrm{R}-1.43-45 \mathrm{~cm}: 9=141-862 \mathrm{~B}-3 \mathrm{X}-1.9-13 \mathrm{~cm} ; 10=141-862 \mathrm{C}-8 \mathrm{R}-1.52-53 \mathrm{~cm}: 11=141-$ $862 \mathrm{C}-8 \mathrm{R}-1.71-75 \mathrm{~cm} ; 12=\mathrm{TT}-24-6: 13=\mathrm{TT}-26-1: 14=\mathrm{TT}-26-4: 15=\mathrm{TT}-26-1: 16=\mathrm{TT}-29-4 \mathrm{R} ; 17=$ TT $-29-5 \mathrm{C}: 18=\mathrm{TT}-29-9 \mathrm{R} ; 19=\mathrm{TT}-29-11-2 ; 20=$ TT $-29-11-3 ; 21=$ TT $-30-3: 22=$ TT $-30-5 ; 23=$ TT $-31-1 \mathrm{~b} ; 24=$ TT $-31-6 a: 25=$ TT $-32-2 ; 26=$ TT $-32-6: 27=$ TT $-33-5 ; 28=$ TT $-33-9: 29=$ TT $-33-10 ; 30=$ TT $-34-9 ; 31=$ TT $-33-9 ; 29=33-10 ; 30$ $=\mathrm{TT}-34-9: 31=\mathrm{TT}-34-11$.

Zone. Later scientists described alkaline olivine basalts and gabbroids with normative nepheline in Saint Paul, Romanche, Siqueiros, and Clarion fracture zones (Kharin, 1983; Batiza and Vanko, 1985; Belevtsev and Shcherbakov, 1989; Kogarko and Rudchenko, 1991). Alkaline olivine basalts in these fracture zones are most frequently associated with the basal parts of seamounts (Hekinian and Thompson, 1976; Hekinian, 1982) and have primary melts derived from deeper sources than MORB. Basalts dredged from the flanks of fracture zones close to the continent generally are more alkaline, with normative nepheline from $5 \%$ to $10 \%$. Such fracture zone basalts are geochemically similar to the basalts considered in this paper.

The subalkaline basalts and the silicic volcanic rocks comprising the Taitao Ridge and the Taitao Ophiolite complex may have formed together in the Pliocene-Pleistocene, synchronously with the arrival at the continental slope and shelf of young buoyant crust along the Taitao Fracture Zone. Formation of new crust along a leaking transform fault could have allowed upper mantle decompression and partial melting to form the primary subalkaline basaltic melts at a greater depth than probably typical of intra-oceanic rift magmas. If the continent side of the fault accommodated a deep magma chamber for a longer time than the oceanic side, it might account for the greater differentiation of the ophiolite as well as its partial crustal contamination (Kaeding et al., 1990). During the accretion stage, the ophiolitic slab comprising rocks formed in the Taitao Fracture Zone was obducted over the pre-Upper Jurassic metamorphic rocks of the Taitao Peninsula.

Basalts from the Taitao Ridge are generally weakly altered to zeolite facies (the "smectite facies" of Kurnosov, 1986), with lowtemperature alteration to smectite the principal process. In contrast, effusives of the Taitao Ophiolite are moderately to strongly altered to zeolite and greenschist facies. Kurnosov (1986) showed that trioctahedral smectite is the main replacement mineral in oceanic effusives. He recognized a "smectite facies" for altered basalts in oceanic crust, which corresponds to the zeolite facies but is distinguished by mineralogy unique to alteration of basalts in contact with sea water. The lower boundary of the "smectite facies" was determined by comparing samples from Hole 504B of Deep Sea Drilling Project Leg 83 (Anderson et al., 1982; Alt et al., 1986) with basalt samples from deep holes in the Troodos Ophiolite in Cyprus, at a depth of $600 \mathrm{~m}$ below the cover of the basaltic basement (Chudaev et al., 1991). Under conditions of the "smectite facies" alteration of basalt, the major chemical process results in hydration and the removal of both rock-forming and trace elements from rocks (Kurnosov, 1986, 1992).

The ophiolitic effusives with a predominance of mixed-layer minerals and minor smectite and chlorite were altered under conditions of the typical transition zone from zeolite facies to greenschist facies. This zone was studied in the lower part of the effusive sequence recovered in Hole 504B, Costa Rica Rift (Kawahata and Kusakabe, 1987), as well as in the Kuyul Ophiolitic terrane (Chudaev and Kurnosov, 1992). The sheeted-dike complex rocks of the Taitao Ophiolite were altered under greenschist facies similar to that observed at Hole 504B (Alt et al., 1986; Kawahata and Kusakabe, 1987). The alteration of these rocks from the Taitao Ophiolite is consistent with alteration of basaltic layer rocks before accretion of the oceanic crust.

A combined series of effusive units and the sheeted-dike complex was sampled for the Taitao Ophiolite, whereas at Site 862 (Taitao Ridge) basalts were recovered only from the uppermost $80 \mathrm{~m}$ or so of a sequence of effusives. Comparison of the alteration in Taitao Ridge basalts with the Taitao Ophiolite sequence in Table 4 shows that the ophiolitic rocks are much more altered than the Taitao Ridge basalts $\left(\mathrm{H}_{2} \mathrm{O}^{+} 1.38\right.$ to 3.66 and 0.14 to $1.30 \mathrm{wt} \%$, respectively).

The assemblage of secondary minerals is similar with a predominance of smectite in both suites, and minor or trace amounts of chlorite, illite, glauconite/celadonite, talc, phillipsite, analcime, quartz, carbonate, and aragonite. A similar secondary mineral assemblage was deter- 
Table 3 (continued).

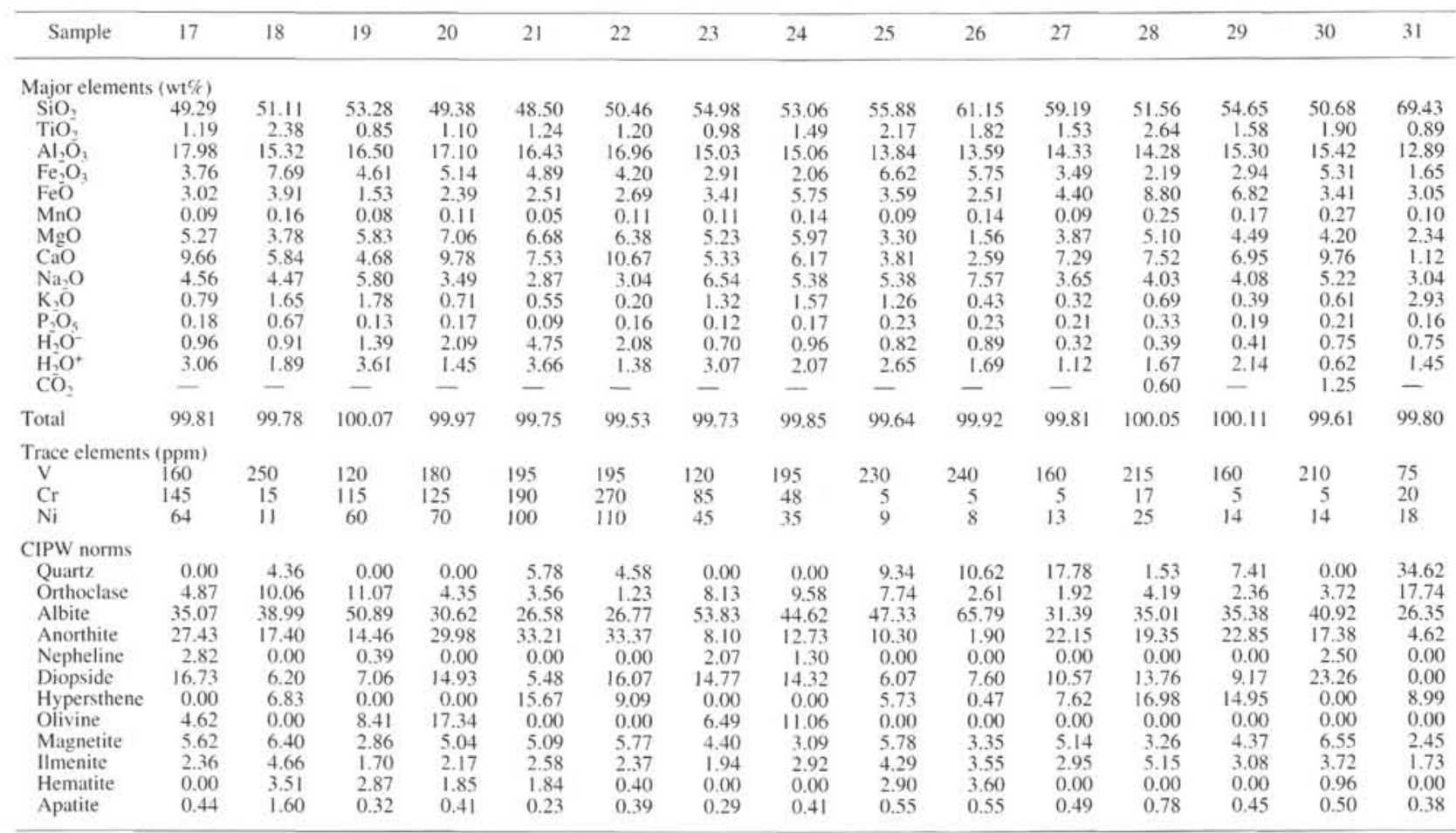

Table 4. Comparison of igneous rock alteration from Site 862 (Taitao Ridge) and the Taitao Ophiolite (Taitao Peninsula).

\begin{tabular}{|c|c|c|c|}
\hline & \multirow{2}{*}{$\begin{array}{c}\text { Site } 862 \\
\text { Basalts }\end{array}$} & \multicolumn{2}{|c|}{ Taitao Ophiolite } \\
\hline & & Effusives & Sheeted dikes \\
\hline Level of alteration & Almosi fresh. low to rarely moderate & Strong to moderate & Moderate to strong \\
\hline Range of $\mathrm{H}_{2} \mathrm{O}^{+}$content (w $1 \%$ ) & $0.14-1.30$ & $1.38-3.66$ & $1.12-2.14$ \\
\hline Secondary clay minerals & $\begin{array}{l}\text { Smectite } \\
\text { Chlorite } \\
\text { Illite } \\
\text { Talc } \\
\text { Glauconite/celadonite }\end{array}$ & $\begin{array}{l}\text { Smectite } \\
\text { Mixed-layer minerals } \\
\text { Chlorite } \\
\text { Illite } \\
\text { Talc }\end{array}$ & $\begin{array}{l}\text { Chlorite } \\
\text { Smectite }\end{array}$ \\
\hline Secondary nonclay minerals & $\begin{array}{l}\text { Quartz } \\
\text { Phillipsite } \\
\text { Carbonate } \\
\text { Arigonite }\end{array}$ & $\begin{array}{l}\text { Quart/ } \\
\text { Analcime } \\
\text { Carbonate }\end{array}$ & $\begin{array}{l}\text { Amphibole } \\
\text { Quartz. }\end{array}$ \\
\hline
\end{tabular}

Note: Italicized secondary clay minerals are dominant among clay minerals.

mined in the upper part of the basalt sequence of the Costa Rica Rift in Hole 504B (Kurnosov et al., 1983). Possibly the superimposed accretionary process weakly influenced the alteration of the uppermost ophiolitic effusives with the formation of partial smectites and particularly mixed-layer minerals among primary smectites.

\section{SUMMARY AND CONCLUSION}

The basalts and silicic volcanic rocks of each suite are comagmatic and may have been derived from subalkaline primary melts of similar composition. Alteration of basalts from the Taitao Ridge (Site 862) is low to rarely moderate with smectite as the main secondary mineral. On the contrary, the effusives and sheeted-dike complex of the Taitao Ophiolite are altered strongly to moderately under zeolite facies (main secondary mineral smectite), greenschist facies (main secondary minerals chlorite and amphibole), and under conditions of the transition zone from zeolite to greenschist facies with widespread formation of mixed-layer minerals.
The basalts and silicic rocks of the Taitao Ridge and the Taitao Ophiolite are, within themselves, parts of comagmatic series and were derived from subalkaline melts of similar composition. The primary melt composition shares some features with both MORB and intraplate rise alkaline basalts. Higher MG for the basalts from the Taitao Ridge suggest that these basalts are slightly more primitive than those sampled from the ophiolite. The subalkaline basalts and the associated silicic volcanic rocks comprising both the Taitao Ridge and the Taitao Ophiolite may have formed synchronously with arrival of young buoyant crust along the Taitao Fracture Zone during the Pliocene-Pleistocene. The additional magmas generated within the transform collision zone took on different characteristics in the two settings, with the inland ophiolite having greater degrees of intermediate effusions, possibly higher extents of crustal contamination, and more extensive alteration. Shallower water eruption also produced a greater degree of vesiculation in these landward units. The ophiolitic slab was then obducted on the pre-Late Jurassic metamorphic rocks of the Taitao Peninsula during the Pleistocene. 

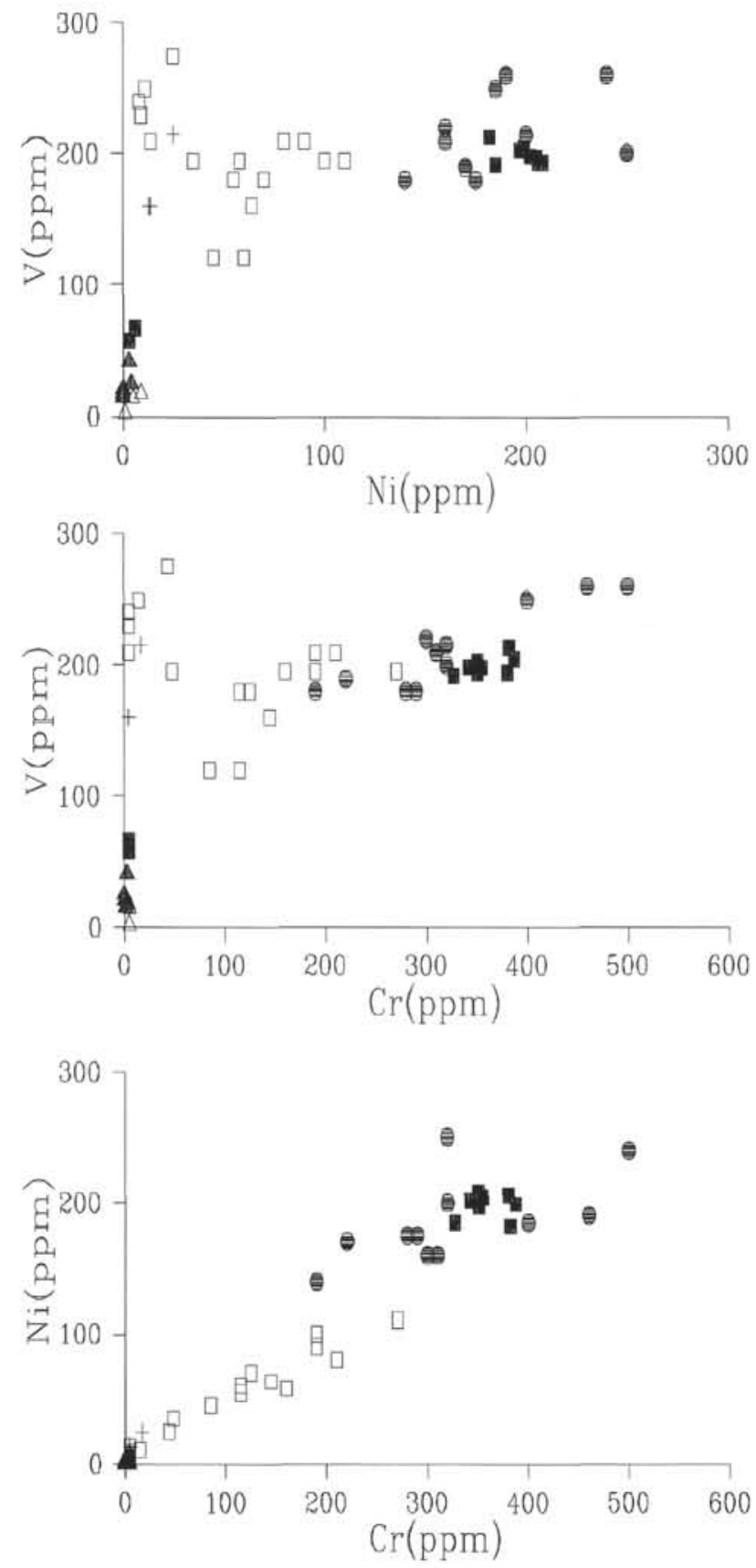

Figure 5. Variation diagrams for selected trace elements. Symbols for sample analyses are the same as for Figure 2.

Alteration of the samples from the Taitao Ridge is low to rarely moderate with smectite as the dominant secondary mineral. In contrast, the samples from the ophiolite's effusives and sheeted dikes are strongly and moderately altered under smectite, transitional (smectite to greenschist), and greenschist facies. The sequence of alteration for the ophiolite is similar to that seen in samples recovered from the Costa Rica Rift in Hole 504B. However, it is also possible that the increased alteration seen in the ophiolite was produced during a second phase of alteration during its obduction. Future work, perhaps by the analysis of samples dredged at locations between Site 862 and the ophiolite, might aid in further defining the relationship between these two apparently related but distinct series of ridge collisioninduced magmatic suites.

\section{ACKNOWLEDGMENTS}

We thank the reviewers for useful critical remarks, N. Kalashnikova and E. Cherkasova for chemical analysis, and A. Sokolova and E. Pokrovskaya for analytical work. John R. Griffin assisted with revision of a preliminary draft of the manuscript. Sampling of the ophiolite was made possible by funds provided under NSF EAR-9106638 to R. Forsythe.

\section{REFERENCES}

Alt, J.C., Honnorez, J., Laverne, C., and Emmermann, R., 1986. Hydrothermal alteration of a $1 \mathrm{~km}$ section through the upper oceanic crust, Deep Sea Drilling Project Hole 504B: mineralogy, chemistry, and evolution of seawater-basalt interactions. J. Geophys. Res., 91:10309-10335.

Anderson, R.N., Honnorez, J., Becker, K., Adamson, A.C., Alt, J.C., Emmermann, R., Kempton, P.D., Kinoshita, H., Laverne, C., Mottl, M.J., and Newmark, R.L., 1982. DSDP Hole 504B, the first reference section over $1 \mathrm{~km}$ through Layer 2 of the oceanic crust. Nature, 300:589-594.

Batiza, R., and Vanko, D., 1985. Petrologic evolution of large failed rifts in the eastern Pacific: petrology of volcanic and plutonic rocks from the Mathematician Ridge area and the Guadalupe trough. J. Petrol., 26:564-602.

Behrmann, J.H., Lewis, S.D., Musgrave, R.J., et al., 1992. Proc. ODP, Init. Repts., 141: College Station, TX (Ocean Drilling Program).

Belevtsev, R.Y., and Shcherbakov, I.B., 1989. Basalts and metabasalts of the Romanche fracture zone. In Shnyrkov, Ye.F. (Ed.), Geology and Metallogeny of the Tropical Atlantic. Akad. Nauk Ukr. SSR, Inst. Geol. Nauk. 99-105.

Cande, S.C., and Leslie, R.B., 1986. Late Cenozoic tectonics of the southern Chile Trench. J. Geophys. Res., 91:471-496.

Cande. S.C., Leslie, R.B., Parra, J.C., and Hobart, M., 1987. Interaction between the Chile Ridge and Chile Trench: geophysical and geothermal evidence. J. Geophys. Res., 92:495-520.

Castillo, P., Batiza, R., Vanko, D., Malavassi, E., Barquero, J., and Fernandez, E., 1988. Anomalously young volcanoes on old hot-spot traces, I. Geology and petrology of Cocos Island. Geol. Soc. Am. Bull., 100:1400-1414.

Chudaev, O., and Kurnosov, V., 1992. Oceanic metamorphism in the Kuyul ophiolitic terrane of the North Kamchatka (Russia). In Kharaka, Y.K., and Maest, A.S. (Eds.), Proc. 7th Int. Symp. Water-Rock Interaction (Vol. 2): Moderate and High Temperature Environments, 7:1639-1642.

Chudaev, O.V., Kurnosov, V.B., Petrachenko, E.D., Kholodkevich, I.V., and Robinson, P.T., 1991. Secondary minerals in the CCSP Drillholes CY-1 and CY-1A. In Gibson, I.L., Malpas, J., Robinson, P.T., and Xenophontos, C. (Eds.), Cyprus Crustal Study Project: Initial Report Holes CY-I and IA. Pap.-Geol. Surv. Can., 61-80.

Drits, V.A., and Tchoubar, C., 1990. X-ray Diffraction by Disordered Lamellar Structures (Theory and Applications to Microdivided Silicates and Carbons): Heidelberg (Springer-Verlag).

Forsythe, R.D., Nelson, E.P., Carr, M.J., Kaeding, M.E., Herve, M., Mpodozis, C., Soffia, J.M., and Harambour, S., 1986. Pliocene near-trench magmatism in southern Chile: a possible manifestation of ridge collision. Geology, 14:23-27.

Forsythe, R.D., Olsson, R.K., Johnson, C., and Nelson, E.P., 1985. Stratigraphic and micropaleontologic observations from the Golfo de Penas-Taitao Basin, southern Chile. Rev. Geol. Chile, 25/26:3-12.

Hekinian, R., 1982. Petrology of the Ocean Floor: Amsterdam (Elsevier).

Hekinian, R., and Thompson, G., 1976. Comparative geochemistry of volcanics from rift valleys, transforms and aseismic ridges. Contrib. Mineral. Petrol., 57:145-162.

Kaeding, M., Forsythe, R.D., and Nelson, E.P., 1990. Geochemistry of the Taitao ophiolite and near-trench intrusions from the Chile Margin Triple Junction. J. S. Am. Earth Sci., 3:161-177.

Kawahata, H., Kusakabe, M., and Kikuchi, Y., 1987. Strontium, oxygen and hydrogen isotope geochemistry of hydrothermally altered and weathered rocks in DSDP Hole 504B, Costa Rica Rift. Earth Planet. Sci. Lett., $85: 343-355$.

Kharin, G.S., 1983. Petrochemical and petrogenetic characteristics of basalts in zones of transform faults. In Bogatikov, O.A., Dmitriyev, Y.I., and

Abbreviations for names of organizations and publications in ODP reference lists follow
the style given in Chemical Abstracts Service Source Index (published by American Chemical Society). 

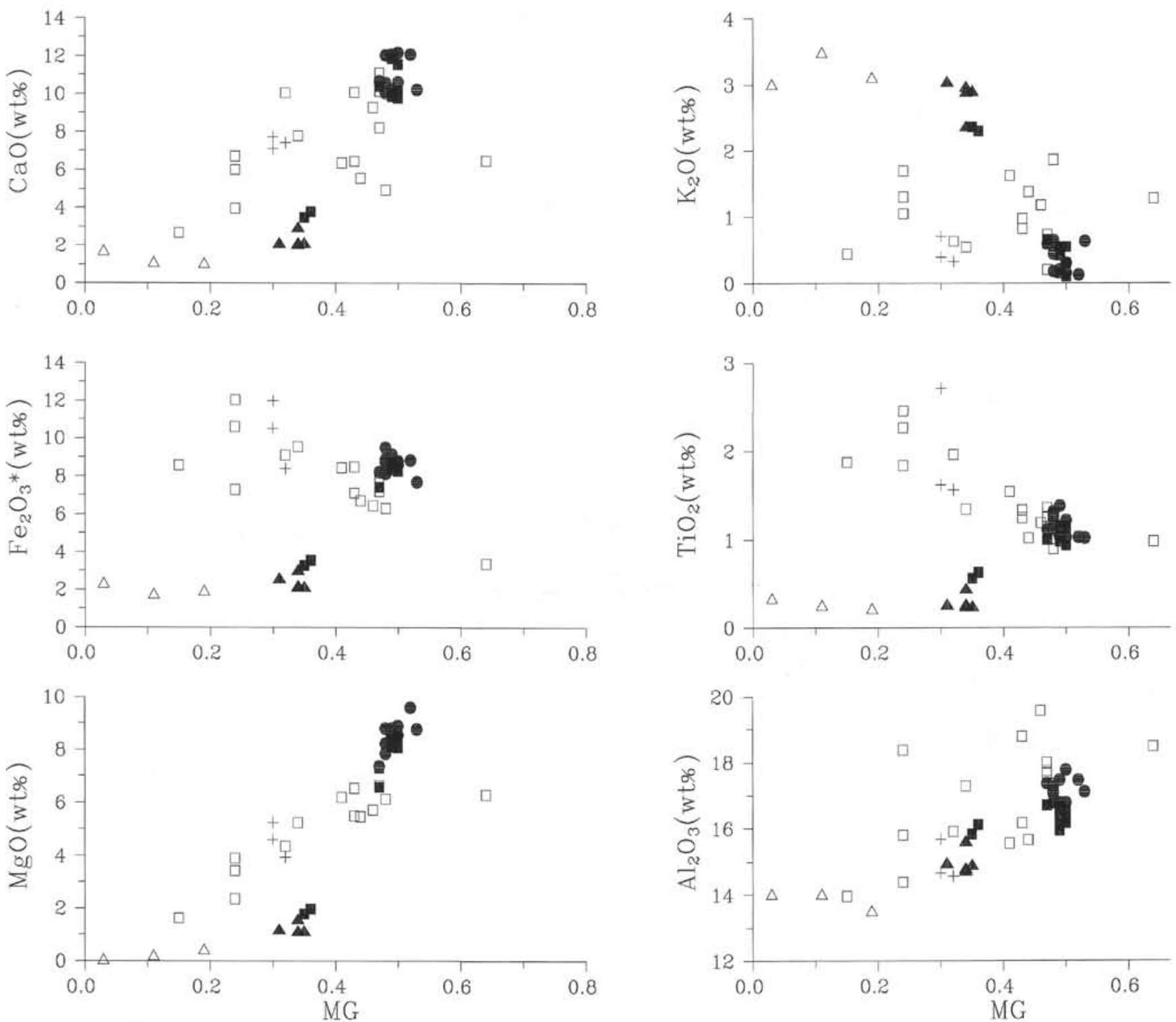

Figure 6. Variation diagrams for $\mathrm{MG}=\mathrm{MgO} /\left(\mathrm{MgO}+\mathrm{Fe}_{2} \mathrm{O}_{3}{ }^{*}\right)$. Symbols for sample analyses are the same as for Figure 2.

Tsvetkov, A.A. (Eds.), Magmatic and Metamorphic Rocks of the Ocean Bottom and Their Genesis: Moscow (Nauka), 245-256.

Kogarko, L.N., and Rudchenko, N.A., 1991. New data on alkalic magmatism in the Clarion fracture zone. Geokhimiya, 8:1204-1210.

Kurnosov, V.B., 1986. Hydrothermal Alterations of Basalts in the Pacific Ocean and Metal-bearing Deposits, Using Data of Deep-sea Drilling: Moscow (Nauka).

, 1992. Hydrothermal water-basalts interaction in the ocean. In Kharaka, Y.K., and Maest, A.S. (Eds.), Proc. 7th Int. Symp. Water-Rock Interaction (Vol. 2): Moderate and High Temperature Environments, $7: 1651-1654$.

Kurnosov, V.B., Kholodkevich, I.V., Chubarov, V.M., and Shevchenko, A.Y., 1983. Secondary minerals in basalt from the Costa Rica Rift. Holes 501 and 504B, Deep Sea Drilling Project, Legs 68, 69 and 70. In Cann, J.R., Langseth, M.G., Honnorez, J., von Herzen, R.P., White, S.M., et al., Init. Repts. DSDP, 69: Washington (U.S. Govt. Printing Office), 573-583.

Macdonald, G.A., 1968. Composition and origin of Hawaiian lavas. In Coats, R.R., Hay, R.L., and Anderson, C.A. (Eds.), Studies in Volcanology: A Memoir in Honor of Howel Williams. Mem.-Geol. Soc. Am., 116:477-522.

Melson, W.G., Jarosevich, E., and Cifelli, R., 1967. Alkali olivine basalt dredged near St. Paul's Rocks, Mid-Atlantic Ridge. Nature, 215:381-383.
Mpodozis, C., Hervé, M., Nasi, C., Forsythe, R.D., and Nelson, E.P., 1985. El magmatismo Plioceno de Peninsula Tres Montes, y su relacion con la evolution del Punto Triple de Chile Austral. Rev. Geol. Chile, 25/26:13-28.

Natland, J.H., and Melson, W.G., 1980. Compositions of basaltic glasses from the East Pacific Rise and Siqueiros fracture zone, near $9^{\circ} \mathrm{N}$. In Rosendahl, B.R., Hekinian, R., et al., Init. Repts. DSDP, 54: Washington (U.S. Govt. Printing Office), 705-723.

Perfiljev, A.S., Achmetjev, M.A., Geptner, A.R., Dmitriev, Y.I.,Zolotarev, B.P., and Samygin, S.G., 1991. Miocene Basalts of Iceland and Problems of Spreading: Moscow (Nauka).

Thompson, G., and Melson, W.G., 1972. The petrology of oceanic crust across fracture zones in the Atlantic Ocean: evidence of a new kind of sea-floor spreading. J. Geol., 80:526-538.

Zolotarev, B.P., and Kotenev, B.N., 1987. Tectonics and magmatism of the Walvis Ridge and the Discovery seamount (Atlantic Ocean). Geotectonics, 20:491-501.

Date of initial receipt: 6 July 1993

Date of acceptance: 4 October 1994

Ms 141SR-031 
V. KURNOSOV ET AL.
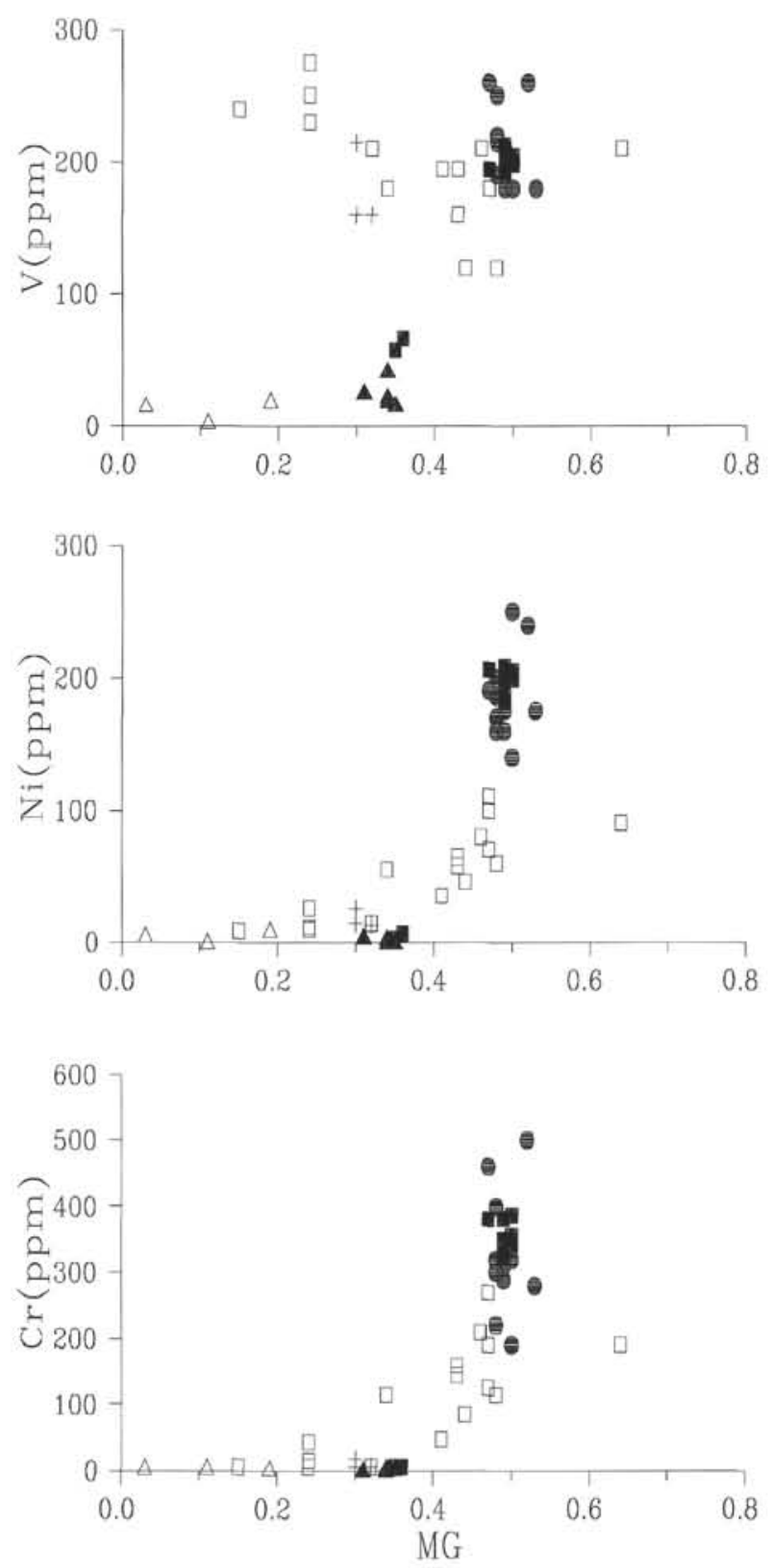

Figure 6 (continued). 